\title{
Nationality as an Influential Variable with Regard to the Social Skills and Academic Success of Immigrant Students
}

\author{
Christian Fernández-Leyva ${ }^{1, *(\mathbb{D})}$, María Tomé-Fernández ${ }^{2}(\mathbb{D})$ and José Manuel Ortiz-Marcos ${ }^{1}$ (D) \\ 1 Department of Research Methods and Diagnosis in Education, Faculty of Education Sciences, \\ University of Granada, 18011 Granada, Spain; jmanuel30@correo.ugr.es \\ 2 Department of Research Methods and Diagnosis in Education, Faculty of Education and Sports Sciences, \\ University of Granada, 52005 Melilla, Spain; mariatf@ugr.es \\ * Correspondence: cristianoronaldo@correo.ugr.es
}

check for

updates

Citation: Fernández-Leyva, C.; Tomé-Fernández, M.; Ortiz-Marcos, J.M. Nationality as an Influential Variable with Regard to the Social Skills and Academic Success of Immigrant Students. Educ. Sci. 2021, 11, 605. https://doi.org/10.3390/ educsci11100605

Academic Editors: Eleni Andreou and Marius Boboc

Received: 14 June 2021

Accepted: 28 September 2021

Published: 1 October 2021

Publisher's Note: MDPI stays neutral with regard to jurisdictional claims in published maps and institutional affiliations.

Copyright: (c) 2021 by the authors. Licensee MDPI, Basel, Switzerland. This article is an open access article distributed under the terms and conditions of the Creative Commons Attribution (CC BY) license (https:// creativecommons.org/licenses/by/ $4.0 /)$.

\begin{abstract}
This study aims to expand the existing scientific, theoretical and empirical knowledge about the influence of the variables age, gender, nationality and place of residence on the probability of developing social skills that generate social wellbeing, and, in addition, to identify the relationship between the most influential variable and the academic success of immigrant students. We hope that the educational community, in an intercultural context, can benefit from and apply this knowledge to assist immigrant students. In this study, a sample of $n=749$ students aged between 12 and 18 , of 41 different nationalities, is analyzed using the Social Skills Scale for Young Immigrants (SSSYI). Data analysis is performed with the SPSS and STATA statistical programs. Multiple linear regression (MLR) analyses verify that nationality is the most influential variable. In addition, when calculating the Pearson correlation, high and positive correlations are found between social skills, nationality and students' grades, with which academic success was measured. In conclusion, we find that students who emigrated from the European continent present better social skills, better social wellbeing and greater academic success.
\end{abstract}

Keywords: social skills; social wellbeing; academic success; online teaching; linear regressions

\section{Justification}

In the last decade, the number of immigrants in Europe has increased. More specifically, this migratory flow has turned Spain into a country of great cultural diversity, especially in its southern regions [1]. This phenomenon is manifested in educational centers, significantly increasing the diversity in classrooms. Therefore, educational spaces are required that pay special attention to the social relations of the peer group, emphasizing and promoting them, in order to reduce segregation and the cultural gap [2]. Given this situation, the main purpose of this research is to expand the existing scientific knowledge on the variables that influence the development of social skills of immigrant students during online learning and to know how the most influential variable in the development of social skills of these students affects their academic success. For this purpose, the Social Skills Scale for Young Immigrants (SSSYI) was applied, an instrument that is considered a perfect candidate for assessing the social skills of young immigrants, making it the only instrument that takes into account the linguistic and comprehension peculiarities of the sample [3]. To test the influence of the variables of age, gender, nationality and place of residence on the probability of social skills development, ANOVA and regression analyses were performed on the input dataset, as these analyses are recommended for the treatment of parametric data [4]. As recommended by Campbell and Lakens [5], the ANOVA statistic was used to estimate the proportion of the variance of the observed data that can be explained by the model. To determine the rejection or acceptance of the hypothesis that the proportion of variance of the explained variables is equal to zero, the F statistic is calculated, which tests whether the null model can be rejected in favor of the full model, with all ex-plan variables 
included [6]. In the multiple linear regression (MLR) analysis, since this calculation is the one recommended by experts for the aforementioned analysis [7], social skills are used as the dependent variable and nationality, place of residence, gender, and age are used as independent variables. In addition, Pearson's correlation was applied, an analysis that indicates that when a high correlation is reached, as described in [8] the closer it is to the value of one indicates to what extent one variable is the cause of another. On the other hand, to check the behavior of the data, a descriptive analysis of the results in the degrees according to the nationalities of the immigrant students analyzed was performed, taking into account that the closer the mean degree grade is to 10 , the higher the academic degree success of the students is. Furthermore, to compare the means of the participants' scores according to their nationality, Tukey's post hoc test was performed. Finally, to check which immigrants' nationalities had more social skills and which had less, and to compare it with their academic success, a contingency table comparing these variables was performed. To obtain the social skills scores, the mean of the answers given to the questionnaire was used, where scores between 1 and 2 correspond to having better social skills, and scores between 3 and 4 correspond to having worse social skills. This is because the instrument is composed of 4 response options, where 1 and 2 mean possessing a specific social skill and 3 and 4 mean not possessing it. Therefore, the lower the scores, the more social skills they possess.

\section{Introduction}

In this cultural context, it is common for the majority culture to dominate minority groups from the aspect of status and power, skewing the social welfare of the latter [9]. On the other hand, there are studies that indicate that there is heterogeneity in the results according to the nationality or nativity of the students in terms of their social skills and academic performance [10]. The culture of young immigrants due to their traditions, experiences and assimilation rates are very heterogeneous; the immigrant paradox can manifest itself differently in various groups or collectives of immigrants [11], which justifies the consideration of the nationality variable in this study. In addition, currently, due to the COVID-19 pandemic, the teaching methodologies of educational centers have been restructured and organized to allow for teaching online, which may have led to the deterioration of the social skills and academic success of some students [12]. Therefore, in this research, the following research question is posed: which variables are most influential in the development of the social skills of immigrant students according to the online learning methodology? In addition, and according to some studies [13] where it is shown that the lower a student's social skills are, the more they fail in school, an attempt is also made to answer a second question: Does the most influential variable (social skills) affect the academic success of these students?

\subsection{Conceptualization: Social Skills and Academic Success}

Before delving into the theoretical foundation of the work, it is necessary to explain the underlying concepts behind it.

The social wellbeing of a student is understood as the functioning of optimal psychological experiences, which favor the prevalence of positive emotions over negative ones and an adequate level of satisfaction with life. This is related to the development of social skills and personal growth, and is frequently referred to as eudaimonic well-being [14].

Social skills are one of the most important processes in the development of the individual; it is manifested through the interaction between the peer group that will allow them to obtain a healthy social life, which over time leads to certain results with different social groups such as emotional, along with meaningful communication with others [15].

Since social skills play an important role within relationships that occur in the same social context [16] Through social skills people become better relationship builders [17], and communication between people, decision-making, problem or conflict resolution, self-management, self-control and competitive skills are improved [18]. These skills are 
mainly acquired in the interaction given in group and diverse environments. Authors such as Tompkins and Villaruel [19] indicate that these skills are necessary to interact with the peer group as well as with their teachers in a positive way, for example, by sharing, cooperating, and having the ability to refrain from problematic behaviors such as aggression and bullying, among others. In this sense, in intercultural settings, Hamaidi et al. [20] and Othman and Ruslan [21] argue the importance of developing social skills among all their students, which will facilitate inclusion and academic success.

In addition, [22] contextualizes it in the intercultural environment, and considers that social wellbeing can be obtained when the social and cultural skills necessary to function effectively in a diverse cultural environment are acquired. As indicated by Baeva et al. [23] the most important factor influencing social skills is the culture constituted by the environment and the family.

On the other hand, regarding academic success, this is defined as a more operational way of looking at academic performance, which is understood as the relationship between the learning process and its tangible results as predetermined values [24]. Also, academic success is understood as performance results that indicate the extent to which individuals achieve the goals and objectives in their educational environment [25]. Along the same lines, authors such as Goegan and Daniels [26] conceptualize academic success as the acquisition of knowledge, cognitive and social skills, and as general satisfaction that generates greater academic capacity and a best achievement due to experiences of academic integration and social skills.

In relation to this, some research shows that the development of positive social skills is related to better performance and therefore to a higher probability of academic success [27], which is a fundamental aspect in intercultural educational contexts [28] where social wellbeing and academic success depend on participation and social integration with the host community [29]. Also, there is evidence that shows that, in most cases, immigrant students do not achieve optimal levels of academic success [30].

Additionally, schools must guarantee the inclusion of all of their students, regardless of their cultural, ethnic or religious origin [31] since, as stated by [32], students belonging to a minority culture, upon coming into contact with the majority group, modify their coping strategies to adapt to their new sociocultural reality. On some occasions, this leads to the development of harmful or dangerous habits that require students to develop certain social skills [33]. These students avoid the impact of traumatic events that may arise in the period of cultural integration [34], which leads to the deregulation of their state of mind and school failure, as well as periods of social isolation, psychological disorder, or social conflict [35].

\subsection{Interculturality, Social Wellbeing and Social Skills in Educational Centers}

Spain, like the entire European continent, has become an intercultural territory $[36,37]$. The great migratory influx has transformed the country, increasing its diversity [38] due to the introduction of different groups that follow different religions, customs and traditions [39]. Due to this 21st century phenomenon, the scientific literature has experienced a boom with regard to research focused on the social and emotional wellbeing of the immigrant population, especially with regard to the role that education has in empowering this school-age population [40].

In the presence of the cultural diversity that currently characterizes the educational context, it is considered essential to define and understand what the paradigm of interculturality consists of [41], since this concept pursues the representation of minority groups, recognizing their interests and needs [42].

According to [43], interculturality allows different social groups to enjoy equal rights in spaces of coexistence and communication. The intercultural approach implies knowing others, valuing them for who they are and fostering spaces for dialogue between all actors [44]. Opportunities for cultural mixing must be staged in educational centers so that they become a meeting place for students of different ethnicities, cultures or religions [45], 
thereby allowing us to analyze and understand the realities of students and their social wellbeing from a tolerant and egalitarian perspective [46].

Thus, interculturality has special relevance in the school context in terms of the social relations of the students, emphasizing and promoting them, in order to reduce qualitative segregation [47] and, consequently, social unrest [48]. Faced with such a situation, and to achieve a recommended state of social wellbeing among students from different cultural groups, the intercultural paradigm considers the development of social skills in these students as the most important factor [49].

\subsection{Social Skills as a Premise of the Social Welfare of Immigrant Students}

According to [50], there are important links between social skills and the social wellbeing of the individual since changes in one of these areas has an impact on the other. Therefore, authors such as [51] argue that intercultural schools should focus on ensuring that all students have equivalent educational opportunities that allow them to acquire the social skills necessary to develop adequate social welfare.

Furthermore, fostering social skills will allow the entire class group, regardless of their cultural origin, to acquire a new capacity for fairer and more equitable relationships [52]. As such, the social relations between these groups will improve [53] alongside their social wellbeing.

However, there is evidence that schools with a large influx of immigrants can lead to the development of social problems to the detriment of equal opportunities to promote the optimal development of immigrant students' social skills and social wellbeing [54]. As such, education, political, and pedagogical intervention is urgently required [55]. As [56] indicates, aspects such as students' positions in the social hierarchy of the educational center will condition the development of skills that allow them to relate optimally with their peers and, in this way, promote an adequate level of social welfare.

\subsection{Online Teaching and Its Inference in the Social Problems of Intercultural Students}

The educational interculturality, due to globalization and migratory social movements, produced in recent decades, has been associated with important changes in the Spanish educational system [57]. This, together with connectivism and the continuous appearance of ICT applications or resources, has been motivating a shift towards an online training model associated with digital competence and technological advances [58]. This has been strengthened in Spai, by home confinement due to the COVID-19 pandemic. It has ecome, during this period, the only methodology used at all educational levels [59].

Through this situation, new deficiencies related to the digital and social divide of different sectors of the Spanish student population have been revealed [60]. These include the problems of connection to the Internet, the lack of technological resources, and the scarcity of training of many teachers for the didactic use of technologies as the most notable deficits [61]. This is particularly the case in minority ethnic and cultural groups, whose migratory situation positions them, in some cases, as students at risk of social exclusion [62]. This is characterized by low economic and linguistic levels that enhance the vulnerability of these groups in online teaching [63]. Given these shortcomings, in Spain it has been established to guarantee the digital inclusion of all these students, by adapting the current educational law (LOMLOE) [64], as well as with regional aid, in which laptops and tablets have been provided to the neediest students [65]. However, through this online teaching the expected educational expectations were not met, for this reason, in the second year of the pandemic, face-to-face teaching has been opted for, taking into account the health standards of social distancing, use of a mask and hand washing [66].

Given this situation, it is necessary to highlight that the educational inequalities that have been observed during online teaching have been different in percentage and severity depending on the ethnic and cultural group to which the student belongs [67].

In this sense, students of African origin have shown themselves to be the most disadvantaged, due to the socioeconomic status in which they find themselves, caused by 
the poor labor regulation of their parents [68]. This, together with the parents' ignorance about the functioning of the educational system and about the language, have been closely related to the lack of adaptation to online teaching [69], which requires specific support and efforts to close the existing cultural gap between African parents and schools [70]. In addition, there are studies that show that African students perceive less family support, since they prioritize work goals and base their decisions on ease and the lower economic cost of enrollment [71]. They therefore present little expectations of academic success [72].

On the other hand, authors such as Heaslip, Hean and Parker identify the Roma ethnic group as another minority group with high deficiencies in adapting to virtual teaching [73]. In this case, in Spain, their relationship with the marginal world positions them as students with low academic performance and high levels of school absenteeism [74], anspect that has been aggravated due to the lack of resources in online teaching [75]. In addition, the scarce training and the little value that Roma parents place on their children's education have overshadowed their academic expectations [76], giving priority, as fwith other ethnic groups, to professional goals. Faced with these problems, there are initiatives that seek to increase the school integration of these students, as well as their academic level, a fact that is sometimes hampered by cultural roots and the discrepancy in educational values on the part of these families [77].

Another minority cultural group that has participated in online teaching in Spain have been Asian students [78]. Unlike the previous ones, in this group, no connection difficulties have been observed, although their parents' understanding of the language has. However, in this situation, above all, it has affected the socialization of Asian students, who were already characterized by having poor social skills [79]. This has been associated with few interactions in the different schools' digital media [80].

This, together with the lack of knowledge of the Spanish educational system by Asian parents [81], has made it difficult to access the minimum educational objectives [82]. For this reason, there are authors [83] who claim that social and academic support should be applied to this group, using specific theoretical and methodological tools that help social and educational integration, reducingin this way the cultural prejudices that the group faces [84].

Finally, it is necessary to highlight the group of Latin American students as another of the groups greatly affected by online teaching in Spain. This group, in which family participation in school was already scarce, has seen this situation worsened with online teaching this [85]. Nuances that especially influence adolescents, whose parents transmit messages of little academic effort to their students [86], prioritizing the world of work over the academic training of their children [87].

Although the dropout rate has decreased in recent years and the achievement gap between Hispanics and other racial groups has narrowed, Latino students continue to be the racial group with the highest dropout rate among the people aged 16 to 24 years in Spain [88]. According to studies [89] the dropout rate in secondary education is still disappointing.

For this group, as for the previous ones, it is also considered that the support programs of educational institutions play a key role in maintaining high educational aspirations and better academic performance while they are in secondary school [90].

However, these cultural references or nationalities should be considered with caution, and not extrapolated to other contexts as shown by some previous studies [91], inn which, for example, it is observed that students of Asian origin achieve low levels of academic success in Spain, in contrast to the educational levels, expectations and reputation of this group in other European countries [92].

All this is due to the lack of social equity in intercultural educational contexts. Online teaching (which we currently find ourselves in the midst of due to the COVID-19 pandemic) may lead to the development new social problems that cross time-space borders, leading to situations of racial or xenophobic cyberbullying [93]. 
Therefore, [94] argues that this new online teaching paradigm has increased cases of cyberbullying worldwide, together with the online insecurity faced by some students due to their culture. Intolerance towards different ethnicities, races or religions has become a risk factor for victims of cyberbullying [95], which have been magnified due to the resettlement of immigrant students in segregated communities [96]. Given these circumstances, understanding these possible risk factors constitutes an important step towards addressing and developing the acquisition of the social skills necessary to deal with these issues [97]. As some studies indicate, the acquisition and development of social skills in the immigrant population facilitates greater inclusion in the educational context, increases their social wellbeing and thereby reduces intercultural social conflicts [98].

The acquisition of social skills in students (immigrant or not) helps them interpret different situations, provides them with stimuli, higher academic performance and provides them access to additional resources that promote development, such as the use of new technologies [13]. They are necessary resources in online teaching caused by the COVID_19 pandemic [99]. And in which the implementation of new social skills that entail virtual support and companionship through digital platforms has been necessary [100].

However, not all behaviors in virtual learning have been positive. Precisely the lack of certain social skills has resulted in cyberbullying situations [101]. This has affected, in the most extreme cases, the academic performance of students [102]. Minority ethnic and cultural groups have been affected due to racist and/or xenophobic attitudes of their peer group [103].

For this reason, as reflected by Maksum, Widiana and Marini [104], it is considered necessary that all students develop social skills in academic environments with a great cultural influx, especially at a time when online teaching is gaining great relevance in educational centers. And in which it is intended, through it, to develop inclusive environments that allow students to learn about local and foreign cultures, and encourage them to develop a sense of heritage and cultural identity [105], and to share them with people who have different backgrounds.

This intracultural online learning will promote values and behaviors, which in turn will improve social skills related to communication, discussion, self-efficacy, and academic performance in online teaching [106] and will help with the use of digital media as a way of learning intercultural communication [107] skills.

\subsection{Social Skills and Academic Success in Immigrant Students}

On the other hand, authors such as [108] equate the optimal development of social skills with academic success. However, this development is affected by variables such as nationality, gender, age, and place of residence.

Regarding nationality, ref. [109] concludes that native-born students have better social skills and better academic performance. Agreeing with this, ref. [110] indicates that immigrant students present lower academic measures when suffering from the impact of adaptation to a new context. Their integration in the host country significantly affects the development of these skills [111].

Furthermore, research links the better development of social skills to female students [112]. This coincides with another study, where it was found that male students were competing with a greater number of social conflicts, less control of their emotions and motivations, and higher rates of academic failure than their female counterparts [113].

Alternatively, some research indicates that, as students grow, the development of certain social skills improves and, with these skills, their academic success also improves due to their maturity [114]. Moreover, several studies affirm that higher levels of education, which are achieved at an older age, lead to greater social wellbeing, indicating the development of better social skills [115]. In addition, it has been found that, as they age, individuals feel happier and more satisfied with their lives and therefore present higher levels of social and psychological wellbeing [116]. 
However, no studies have been found that relate students' place of residence to the development of social skills. However, one investigation showed that, in places of residence where a greater number of their compatriots live, the adaptation of immigrant students improves, and with this, the time taken to achieve academic success is reduced [117].

\subsection{Theoretical Foundations of the Instrument Used}

Therefore, it is necessary to mention the value and novelty of the research, since it measures, for the first time, the acquisition of social skills and academic success among immigrant students in digitized educational contexts in which the social problems of intercultural students are emphasized [118].

This study uses an adapted and validated instrument, called the Social Ability Scale for Young Immigrants (SSYI) [119], made up of six dimensions that evaluate the following aspects: the ability to know how to say no and end interactions; self-expression in situations related to social rights; defense of one's own rights; the ability to express anger and disagreement; the ability to make requests; and the ability to know how to initiate interactions with the opposite sex.

The first dimension measures the ability to say no and end interactions since, as indicated by [120], immigrants who do not acquire this skill experience lower levels of sociability and frustration, unlike immigrants who do acquire it, who are able to adapt to the prevailing levels of sociability in their destination country. The second dimension, self-expression in social situations, consists of the ability for self-expression, which allows immigrant students to express themselves in the broader community, and, in turn, acquire and develop their social skills in a way that is appropriate in the host environment [121]. The third dimension encompasses the defense of one's rights. This dimension consists of students defending their rights to access free education, medical care, the world of work, and, in addition, being recognized by the host society, which must make a greater effort to improve the quality of life of immigrants [122].

As for the fourth dimension, expression of anger or disagreement, this concerns the ability of students to express their emotions in increasingly complex situations, since it allows them to regulate themselves in different situations that can lead to anger, as this is a prerequisite to being able to function as a member of society [123].

The fifth dimension consists of the ability to make requests, which is related to the research of [124], who refers to the ability to make requests of other people, which makes it possible to solve immediate and future problems and allows for greater social skills acquisition.

The sixth and final dimension involves initiating positive interactions with the opposite sex. According to [125], this dimension leads immigrant students to interact with friends of the opposite sex in order to improve their capacity to relate to other members of society. This can be accomplished by interactions based on trust, reciprocity, mutual support, and friendly relationships between the sexes.

\section{Materials and Methods}

\subsection{Objectives and Hypothesis}

In order to answer the question: Does the most influential variable of the social skills affect the academic success of these students? the following general objectives are proposed:

1. Expand the existing scientific knowledge regarding the variables influencing the development of social skills of immigrant students during online learning.

2. Know how the most influential variable in the development of social skills of these students affects their academic success.

The review of the scientific literature shows the importance of this study and lays the foundations for the initial hypotheses raised: The first hypothesis determines that nationality is the most influential variable analyzed in the acquisition of social skills of immigrant students during online teaching. And the second hypothesis is that in an online 
learning context, students who belong to a nationality with higher social skills will have greater academic success.

\subsection{Sample}

This research was planned with an ex post facto quasi-experimental design, in which a sample of $n=749$ immigrant students between 12 and 18 years old participated $(X=14.17$, $\mathrm{SD}=1.67)$, of which $397(53 \%)$ belonged to the female gender and $352(47 \%)$ to the male. The selection of the sample was carried out by means of intentional non-probabilistic sampling in which students at collaborating schools who wished to participate were able to do so. Despite this, the sample is sufficiently representative, exceeding the ratio of 10:1 (participants vs. items of the instrument) [126].

In addition, the participants resided in 10 different cities located in southern Spain (Table 1). These cities were selected since they are the ones that reflect a higher rate of immigrant students per school ratio [127].

Table 1. Percentage of number of students by place of residence.

\begin{tabular}{ccc}
\hline Place of Residence & \% & Participants \\
\hline Granada & 34.8 & 261 \\
Cádiz & 13.6 & 102 \\
Málaga & 11.5 & 86 \\
Almería & 10.3 & 77 \\
Huelva & 8.7 & 65 \\
Ceuta & 4.7 & 35 \\
Melilla & 4.5 & 34 \\
Jaén & 4.3 & 32 \\
Córdoba & 3.9 & 29 \\
Sevilla & 3.7 & 28 \\
Total & 100 & 749 \\
\hline
\end{tabular}

Source: own calculations.

Regarding their origin, $238(31.8 \%)$ immigrant students came from the African continent, $216(28.8 \%)$ from the European continent, 177 (23.6\%) from the American continent, and $118(15.8 \%)$ from the Asian continent (Table 2). The distributions of the countries of origin of immigrant students are shown in Table 3.

Table 2. Distribution of the continents of origin of the immigrant students.

\begin{tabular}{clc}
\hline Continent & $\mathbf{N}^{\circ}$ & $\%$ \\
\hline Africa & 238 & 31.8 \\
Europe & 216 & 28.8 \\
America & 177 & 23.6 \\
Asia & 118 & 15.8 \\
\hline
\end{tabular}

Source: own calculations.

\subsection{Instrument}

The instrument used in this research, the Social Skills Scale for Young Immigrants (SSSYI), has a psychometric structure that presents excellent values [128] and has a global internal consistency level of 0.82 and levels above 0.81 for each of its dimensions (Table 4). 
Table 3. Distribution of the nationalities of immigrant students.

\begin{tabular}{|c|c|c|c|}
\hline Continent & Nationality & $\mathbf{N}^{\circ}$ & $\%$ \\
\hline \multirow[t]{7}{*}{ Africa } & Morocco & 145 & 60.9 \\
\hline & Senegal & 25 & 10.5 \\
\hline & Nigeria & 23 & 9.7 \\
\hline & Ivory Coast & 18 & 7.5 \\
\hline & Mali & 15 & 6.3 \\
\hline & Algeria & 10 & 4.2 \\
\hline & Guinea & 2 & 0.9 \\
\hline \multirow[t]{15}{*}{ Europe } & Romania & 149 & 69 \\
\hline & Germany & 13 & 6.15 \\
\hline & France & 11 & 5 \\
\hline & Portugal & 11 & 5 \\
\hline & Italy & 10 & 4.66 \\
\hline & England & 9 & 4.21 \\
\hline & Ukraine & 3 & 1.38 \\
\hline & Russia & 3 & 1.38 \\
\hline & Bulgaria & 1 & 0.46 \\
\hline & Greece & 1 & 0.46 \\
\hline & Latvia & 1 & 0.46 \\
\hline & Switzerland & 1 & 0.46 \\
\hline & Sweden & 1 & 0.46 \\
\hline & Poland & 1 & 0.46 \\
\hline & Georgia & 1 & 0.46 \\
\hline \multirow[t]{14}{*}{ America } & Ecuador & 57 & 32.2 \\
\hline & Bolivia & 33 & 18.64 \\
\hline & Peru & 18 & 10.17 \\
\hline & Colombia & 16 & 9.04 \\
\hline & Argentina & 15 & 8.5 \\
\hline & Brazil & 12 & 6.78 \\
\hline & Venezuela & 9 & 5 \\
\hline & Mexico & 9 & 5 \\
\hline & Paraguay & 2 & 1.12 \\
\hline & Uruguay & 2 & 1.12 \\
\hline & Cuba & 1 & 0.56 \\
\hline & Honduras & 1 & 0.56 \\
\hline & Dominican Rep. & 1 & 0.56 \\
\hline & Chile & 1 & 0.56 \\
\hline \multirow[t]{5}{*}{ Asia } & China & 52 & 44 \\
\hline & Japan & 41 & 35 \\
\hline & Pakistan & 11 & 9 \\
\hline & Syria & 9 & 7 \\
\hline & South Korea & 5 & 4 \\
\hline
\end{tabular}

Source: own calculations.

Table 4. Internal consistency of the six dimensions of the Social Skills Scale for Young Immigrants (SSSYI)

\begin{tabular}{lcc}
\hline Dimensions & $\alpha$ & $\mathbf{N}^{\circ}$ Items \\
\hline 1. Being able to say no and end interactions & 0.89 & 7 \\
2. Being able to express oneself in social situations & 0.81 & 8 \\
3. Being able to defend one's own rights & 0.81 & 4 \\
4. Being able to express anger and disagreement & 0.81 & 3 \\
5. Being able to make requests to others & 0.85 & 4 \\
6. Being able to initiate positive interactions with the opposite sex & 0.82 & 3 \\
Total & 0.82 & 29 \\
\hline
\end{tabular}

Source: own calculations. 
The instrument consists of 37 initial items, which were reduced to 33 items using the expert judgment technique. Next, an exploratory factor analysis was carried out in which the instrument was reduced to 29 items and, finally, a confirmatory factor analysis was carried out that confirmed the previous 29 items, in which CFI values of $n=0.877$, TLI values of $n=0.852$ and RMSEA values of 0.04 were obtained, meaning that the instrument was validated and had a high level of reliability $\alpha=0.82$.

The first part of the questionnaire collected sociodemographic data regarding the selected sample, such as students' ages, gender, place of residence and nationality. Additionally, a second part made up of 29 items was divided into six dimensions: ability to say no and end interactions (seven items); self-expression in social situations (eight items); defense of one's own rights (four items), ability to express anger and disagreement (three items); ability to make requests to others (four items); and the ability to initiate positive interactions with people of the opposite sex (three items). The items were evaluated using a Likert-type scale, which measured the frequency of the statement from one to four, with one being equal to never, two equal to almost never, three equal to almost always and four equal to always.

On the other hand, the range of scores for the proposed dimensions ranged from seven to 28 for the first dimension, from eight to 32 for the second dimension, from four to 16 for the third and fifth dimensions, and from three to 12 for the fourth and sixth dimensions.

With regard to the six dimensions, the first of them, the ability to say no and end interactions, aims to assess the ability of young people to refuse to perform a task when they believe that it is not fair, since, according to [129], saying no is a method of expressing one's social skills and defending one's right to choose. The second dimension, self-expression in social situations, aims to assess the degree to which young immigrants are capable of carrying out the activities of daily life, as authors such as [130] indicate that their confidence can be analyzed in this way. [131] argues that one of the indicators of selfexpression in social situations is confidence in one's own abilities. With respect to the third dimension, the defense of their own rights, this is used to detect the ability of young immigrants to demonstrate their knowledge about their own rights when they visit a public establishment. In relation to this, [132] highlights the right to security, the right to be informed, the right to be heard, the right to choose, the right to privacy and the right to compensation as fundamental for the social development of a subject [133]. The fourth dimension, expression of anger or disagreement, is identified with the ability of immigrant students to externalize their anger towards other people, which [134] defines as a negative emotional response to unfair behavior by others, also affirming that this ability is used as a shield against the harm of others. The fifth dimension is the ability to make requests, which is intended to measure the degree to which young immigrants are capable of asking for something they consider to be theirs, which forces the individual leave their internal forum and externalize a problem that they cannot solve by themselves. In this way, the individual must relate to others, putting their shyness aside [135]. The sixth and last dimension involves immigrant students' ability to initiate positive interactions with the opposite sex, through which we intended to assess whether the participants were capable of holding conversations and interacting with people of the opposite sex. In relation to this, [136] states that this ability is related to spontaneously giving a compliment, or simply being able to talk to someone who is attractive.

\subsection{Data Collection Procedure}

For data collection in the educational centers, participation was requested by email and telephone calls to various managers. Subsequently, the parents and legal guardians of immigrant students were asked to sign an informed consent form to confirm that they consented to participate in the study. We explained that this participation would be completely anonymous and that the confidentiality of the data would be guaranteed. Regarding the administration of the questionnaire, it was provided virtually and in Spanish to students, through a link provided by their teacher in class. The instrument was completed in approx- 
imately 10 to $30 \mathrm{~min}$ using the Google Forms platform. The help of an online translator was requested only four times by the students since most of the immigrant students surveyed were fluent in Spanish and had passed their literacy classes. The questionnaire was tested with immigrant students, and this instrument was decided to be administered in Spanish because the students had a good level of the language, which was verified by their own teachers who were sent a document to ensure that this was the case. Finally, at the end of the academic year, the teachers were asked for the final grades in each subject obtained by the students who participated in the study. These grades were sent by email to the authors of this work and represent the average of the marks obtained during the course in each of the subjects.

Both in the administration of the questionnaire and in the collection of academic qualifications, the ethical recommendations provided in the Declaration of Helsinki (1975), later updated in Brazil in 2013, were followed, and the Ethics Committee of the University of Granada approved this study (reference code: 742/CEIH/2018). We assessed the variables of nationality and gender, which, a priori, can generate controversies when related to descriptions of students' capacities. We also took into account the existing immigration policy, as reflected in the deontological code of the regulations mentioned above.

\subsection{Data Analysis Procedure}

In the tabulation and analysis of the data, the statistical program SPSS version 25 was used, following the statistical indications and data analysis techniques proposed by authors such as P [137]. Prior to this step, we carried out the coding of the independent variables. For the gender variable, the number 1 was used to code for male gender and the number 2 for female gender. For the nationality variable, the number 1 was used to refer to immigrants from the African continent, the number 2 for the continent of Europe, 3 for the Asian continent and 4 for the American continent. For the variable place of residence, the number 1 was used to code for immigrants who resided in the province of Granada, the number 2 for those who resided in the province of Malaga, 3 for Almería, 4 for Jaén, 5 for Córdoba, 6 for Cádiz, 7 for Seville, 8 for Huelva, 9 for Melilla and 10 for immigrants residing in Ceuta. Finally, regarding age coding, this was done using the ages of the students: $12,13,14,15,16,17$ and 18 .

Following this procedure, we were left with a final data set of three nominal variables (gender, nationality and place of residence) and one ordinal variable (age). To check the probability of immigrant students developing their social skills according to the variables of age, gender, nationality and place of residence, multiple linear regression (MLR) analysis was carried out using STATA statistical software. Through this analysis, a model can be created that defines the relationship between the outcome or dependent variable (social skills) and the independent or explanatory variables [138]. Multiple linear regression (MLR) is one of the statistical methods that attempts to model the correlation between the variables involved and a response variable that depends on the linear equation in the observed data.

The MLR model is as follows:

$$
Y=\beta 0+\beta 1 X 1+\beta 2 X 2+\ldots+\beta p X p+\varepsilon
$$

where $\mathrm{Y}$ is the dependent variable, $\beta 1$ is the intercept, $\mathrm{X} 1$ is the independent variable, and $\varepsilon$ refers to random measurement errors [8].

\section{Results}

\subsection{Data Analysis \\ MLR Model}

In this study, the values for ANOVA $(\mathrm{F}=4.17, p=0.001)$ indicated the significance of the complete model and, therefore, the validity of the model when making predictions about students' social skills, as previously shown [139] (Table 5). The R2 and the root mean square error (RMSE) of the independent variables were then calculated to check the fit of 
the model and the ability of the SSSYI scale to predict social skills since, according to some theorists, this is the best analysis for this calculation [103].

Table 5. ANOVA results for the regression model of the age, gender, nationality and place of residence variables.

\begin{tabular}{|c|c|c|c|c|c|c|c|}
\hline \multicolumn{8}{|c|}{ ANOVA } \\
\hline Regression & $\begin{array}{c}\text { Sum of } \\
\text { squares regress } \\
306.54\end{array}$ & $\begin{array}{l}\text { Df regress } \\
5\end{array}$ & $\begin{array}{c}\text { Sum of } \\
\text { squares residual } \\
10977.39\end{array}$ & $\begin{array}{c}\text { Mean squares regress } \\
61.31\end{array}$ & $\begin{array}{c}\text { Mean squares residual } \\
14.70\end{array}$ & $\begin{array}{c}\mathrm{F} \\
4.17\end{array}$ & $\begin{array}{l}\text { Sig. } \\
0.001\end{array}$ \\
\hline
\end{tabular}

Source: own calculations.

The multiple linear regression (MLR) analyses of the input data set for social skills obtained values of $R=0.888$ and $R 2$ Adjusted $=0.787$. The value of $R 2$ indicates the percentage at which the intended instruments were measured since, according to some theorists, this is the best analysis for this calculation [140]. In the case of R2 Adjusted $=0.787$, this indicates that the SSSYI measures $78.7 \%$ of social skills as a function of the nationality, place of residence, gender and age variables. The results showed that RMSE was $=0.712$, indicating that the model fit scores below 0.712 correctly as, according to some studies, this indicates that the adjustment is adequate [141] (Table 6). In order to verify which of the variables (nationality, place of residence, gender or age) was the one that had the most weight in the research and, therefore, was the greatest predictor of social skills, a comparison of competing model coefficients was calculated.

Table 6. Results of multiple linear regression (MLR) analysis of the input data set for social skills.

\begin{tabular}{ccc}
\hline $\mathbf{R}$ & $\mathbf{R} 2$ Ajusted & RMSE \\
\hline 0.888 & 0.787 & 0.712 \\
\hline
\end{tabular}

Source: own calculations.

The comparison of competing model coefficients was obtained with the variables with less impact, which were the place of residence $(=0.242)$, age $(=0.135)$ and gender (with a coefficient of $=0.04$ ) (Table 7). Therefore, it can be deduced that social skills are linked to the nationality of the young immigrant participants to a greater degree than place of residence, age and gender. Subsequently, the correlation between the social skills, nationality and qualifications variables was corroborated by calculating the Pearson correlation, ass recommended [142] (Table 8).

Table 7. Comparison of competing model coefficients of multiple linear regression analysis.

\begin{tabular}{cc}
\hline \multicolumn{2}{c}{ Comparison of Competing Models } \\
\hline Place of residence & 0.242 \\
Age & 0.135 \\
Gender & 0.040 \\
\hline
\end{tabular}

Source: own calculations.

Table 8. Correlation between social skills, nationality and qualifications.

\begin{tabular}{cc}
\hline & Pearson's Correlation \\
\hline & \\
Social Skills & Qualifications \\
Nationality & 0.937 \\
\hline
\end{tabular}

Source: own calculations.

The value of the mean academic scores achieved by the participants ranged between 4.33 and 9.22, with the latter being the highest. The lowest score corresponds to immigrants of Korean origin, followed by Chinese students with 4.34 and Japanese students with 4.38. On the other hand, the best marks were obtained by immigrants from Germany with 9.22, followed by the English with 8.33 and the Portuguese with 8.22. (Table 9) 
Table 9. Descriptive statistics of the mean academic success of the students according to their nationality.

\begin{tabular}{|c|c|c|}
\hline & Nationality & Mean \\
\hline 1 & Germany & 9.22 \\
\hline 2 & England & 8.33 \\
\hline 3 & Portugal & 8.22 \\
\hline 4 & France & 8.13 \\
\hline 5 & Switzerland & 8 \\
\hline 6 & Mexico & 7.92 \\
\hline 7 & Uruguay & 7.83 \\
\hline 8 & Italy & 7.70 \\
\hline 9 & Chile & 7.33 \\
\hline 10 & Cuba & 7 \\
\hline 11 & Russia & 7 \\
\hline 12 & Sweden & 7 \\
\hline 13 & Argentina & 6.90 \\
\hline 14 & Brazil & 6.75 \\
\hline 15 & Paraguay & 6.70 \\
\hline 16 & Venezuela & 6.69 \\
\hline 17 & Bulgaria & 6.67 \\
\hline 18 & Bolivia & 6.54 \\
\hline 19 & Peru & 6.50 \\
\hline 20 & Colombia & 6.30 \\
\hline 21 & Ecuador & 6.21 \\
\hline 22 & Ukraine & 6 \\
\hline 23 & Guinea & 6 \\
\hline 24 & Domin. R. & 6 \\
\hline 25 & Greece & 6 \\
\hline 26 & Latvia & 6 \\
\hline 27 & Poland & 6 \\
\hline 28 & Algeria & 5.86 \\
\hline 29 & Nigeria & 5.83 \\
\hline 30 & Morocco & 5.76 \\
\hline 31 & Mali & 5.75 \\
\hline 32 & Senegal & 5.69 \\
\hline 33 & Honduras & 5.33 \\
\hline 34 & Syria & 5.33 \\
\hline 35 & Ivory Coast & 5.25 \\
\hline 36 & Georgia & 5 \\
\hline 37 & Romania & 4.84 \\
\hline 38 & Pakistan & 4.67 \\
\hline 39 & Japan & 4.38 \\
\hline 40 & China & 4.34 \\
\hline 41 & South Korea & 4.33 \\
\hline
\end{tabular}

Source: own calculations.

Tukey's post hoc test (Table 10) verified that the majority of grades had a level of significance below 0.05 and were homogeneous, except for grades 4 and $8 ; 4$ and 9; 5 and 7; 6 and $7 ; 8$ and 9; and 9 and 10. Significant differences were found between these grades and therefore they differed from each other due to their heterogeneity [143].

As can be seen in Table 11, the immigrant students who have better social skills are of the German, French and Portuguese nationalities, and they agree that their academic success is high, the average grade obtained during the school year being 9.22 for students of German origin, 8.22 for those of Portuguese origin and 8.13 for those of French origin. On the opposite side are the immigrant students who have the worst social skills, which are those from China, Japan and Pakistan, and they agree that their academic success is low, with the average of the grades obtained during the course being 4.67 for the students. of Pakistani origin, 4.38 for those of Japanese origin and 4.34 for those of Chinese origin. 
Therefore, when checking these scores, it can be observed how having better social skills is related to greater academic success.

Table 10. Tukey's multiple comparison test of the means of academic success according to nationality.

\begin{tabular}{ccccc}
\hline Difference of Levels & Diference of Means & EE Difference & IC of 95\% & Sig. \\
\hline Mixture 4-Mixture 5 & 9.219 & 1.449 & $(4.94,13.50)$ & 0.000 \\
Mixture 4-Mixture 6 & 12.323 & 1.458 & $(8.01,16.63)$ & 0.000 \\
Mixture 4-Mixture 7 & 10.119 & 1.632 & $(5.30,14.94)$ & 0.000 \\
Mixture 4-Mixture 8 & 2.166 & 1.800 & $(-3.16,7.49)$ & 0.893 \\
Mixture 4-Mixture 9 & -0.866 & 2.465 & $(-8.15,6.42)$ & 1.000 \\
Mixture 4-Mixture 10 & -15.132 & 5.087 & $(-30.17,-0.09)$ & 0.047 \\
Mixture 5-Mixture 6 & 3.105 & 1.034 & $(0.05,6.16)$ & 0.044 \\
Mixture 5-Mixture 7 & 0.091 & 1.267 & $(-2.85,4.65)$ & 0.992 \\
Mixture 5-Mixture 8 & -7.052 & 1.478 & $(-11.42,-2.68)$ & 0.000 \\
Mixture 5-Mixture 9 & -10.084 & 2.241 & $(-16.71,-3.46)$ & 0.000 \\
Mixture 5-Mixture 10 & -24.351 & 4.982 & $(-39.08,-9.62)$ & 0.000 \\
Mixture 6-Mixture 7 & -2.204 & 1.277 & $(-5.98,1.57)$ & 0.599 \\
Mixture 6-Mixture 8 & -10.157 & 1.487 & $(-14.55,-5.76)$ & 0.000 \\
Mixture 6-Mixture 9 & -13.189 & 2.246 & $(-19.83,-6.55)$ & 0.000 \\
Mixture 6-Mixture 10 & -27.456 & 4.984 & $(-42.19,-12.72)$ & 0.000 \\
Mixture 7-Mixture 8 & -7.953 & 1.658 & $(-12.85,-3.05)$ & 0.000 \\
Mixture 7-Mixture 9 & -10.985 & 2.363 & $(-17.97,-4.00)$ & 0.000 \\
Mixture 7-Mixture 10 & -25.252 & 5.038 & $(-40.15,-10.36)$ & 0.000 \\
Mixture 8-Mixture 9 & -3.032 & 2.483 & $(-10.37,4.31)$ & 0.886 \\
Mixture 8-Mixture 10 & -17.299 & 5.095 & $(-32.36,-2.24)$ & 0.013 \\
Mixture 9-Mixture 10 & -14.267 & 5.366 & $(-30.13,1.60)$ & 0.110 \\
\hline
\end{tabular}

Source: own calculations.

Table 11. Contingency table comparing immigrant skills with more and less social skills and their academic success.

\begin{tabular}{ccc}
\hline Nacionality & More Social Skills & Academic Success \\
\hline Germany & 1.155 & 9.22 \\
France & 1.169 & 8.13 \\
Portugal & 1.212 & 8.22 \\
\hline Nacionality & More Social Skills & Academic Success \\
\hline China & 3.87 & 4.34 \\
Japan & 3.66 & 4.38 \\
Pakistan & 3.42 & 4.67 \\
\hline
\end{tabular}

Source: own calculations.

\section{Discussion}

The objectives of this study consisted, on the one hand, of attempting to expand the scientific knowledge on the influence of the variables of nationality, gender, age and place of residence on the development of social skills among immigrant students, and, on the other hand, to assess the relationship between the most influential variable influencing the development of social skills and the academic success achieved by immigrant stu-dents during the online learning process (initiated due to the COVID-19 pandemic).

Given this situation, it should be mentioned that the large migratory influx has transformed Europe and, more specifically, Spain [1]. Due to this 21st century phenomenon, the scientific literature has experienced a boom with regard to research focused on the so-cial and emotional wellbeing of the immigrant population, especially with regard to the role that education has in empowering the school-age population [40]. Therefore, au-thors such as [41] consider the paradigm of interculturality as essential to the social and emotional wellbeing of the immigrant population, since it seeks the representation of immigrant groups or minority groups, recognizing their interests and needs in society [46]. 
Promoting equality and social relations between different cultural groups in educational centers seeks to reduce the existing cultural gap [54]. However, even in these contexts, it is common for the majority culture to position itself as superior to minority groups due to its status and power, to the detriment of the social welfare of immigrant students [9]. In addition, this social gap may be exacerbated by socio-economic and cultural exclusion within educational institutions [143]. This has caused an increase in segregation, leaving to cyber violence perpetrated by dominant groups [47]. Moreover, due to the COVID-19 pandemic, a methodological shift occurred from face-to-face to digitized teaching, leading to an increase in the social problems of said students, even crossing the boundaries of time and space [105].

In this sense, in their study, Ref. [11] reveal that, through this new methodology, differences in access to and appropriation of technology are intensified based on the diverse cultural backgrounds and socioeconomic status of the students.

Faced with such a situation, some theorists recommend that interculturality should be promoted in diverse educational contexts in order to favor the socialization of all students and thus lead them to acquire new social skills in order to achieve optimal social wellbeing [49].

Based on this, a study that looks to expand the existing scientific knowledge on the variables influencing the development of the social skills of these students is justified. Re-garding this objective, the results show that, among the variables analyzed, such as na-tionality, gender, age and place of residence, the nationality of immigrant students seems to have the biggest impact on their acquisition of said skills. This aspect also coincides with previous research [24] in which authors such as [143] highlighted nationality as one of the most influential factors in the development of social skills in immigrant students. According to [144], this may be due to the fact that the traditions, cultures and customs of each nationality determine the intercultural dialogue that takes place and, with it, the acquisition (or not) of certain social skills [39].

On the other hand, and taking into account the second objective of this research, the results obtained show that the social skills of the immigrant students analyzed have a positive correlation with the academic qualifications they achieved. This is in agreement with another study showing that the development of positive social skills is related to better academic performance, and, therefore, to a higher probability of academic success [121].

The results obtained also reflect the positive correlation between the nationality variable, the variable that most influences the social skills of these students, and their grades, which are considered a reflection of their academic success. In the analyses of the nationality variable, it is revealed that the highest level of academic success is indicated in stu-dents of European origin, such as those from Germany, England or Portugal, while the students who obtained lower grades and, therefore, less academic success, were students from China, Japan and South Korea. These results coincide with previous research [122], where it was identified that, depending on the students' nationality, a different degree of integration is achieved in the host country, which significantly influences their academic performance and success.

The findings cannot be extrapolated to the entire Spanish context, and the reason for this lies in the peculiarities of the analyzed region, where there is a lower representation of the nationality of some immigrants than in other areas of the country. This means that the results obtained should be considered with caution, although the sample selection meets statistical requirements established by Williams-Washington and Mills [145], where it is known that the participant-element ratio must be at least 10: 1 .

\section{Conclusions}

We believe that our findings confirm each of the hypotheses discussed in this study. Firstly, we found that the nationality of the evaluated students is the most influential var-iable in the development of their social skills and, therefore, their social wellbeing. 
On the other hand, and taking into account the second hypothesis raised, the results obtained show that the social skills of the analyzed students have a positive correlation with the academic grades they achieved. Additionally, the same positive correlation also occurs between the nationality variable and the academic success of the studied students.

More specifically, this study shows that students of European origin show a greater development of their social skills and greater academic success.

These data exemplify the need for educational and family projects that focus on the development of social skills in immigrant students in order to improve not only their so-cial wellbeing, but also their academic success. Therefore, educational centers must gen-erate awareness of this issue and develop prevention and intervention actions that favor the inclusion of all students, and in which xenophobic values towards cultural diversity are avoided and the coexistence of responsible citizens is promoted.

Lastly, it should be mentioned that the findings obtained in this study revealed that the SSSYI scale, used to measure the data, correctly predicts the social skills of young im-migrants based on their nationality, gender, age and place of residence.

\section{Limitations}

The study has several limitations that require consideration when interpreting the findings. This research used a quantitative methodology, which can provide limited information regarding the social skills, social wellbeing and academic success of immigrant students. Therefore, it is recommended that the study be expanded via investigations that collect qualitative data in order provide complementary information to accompany the current findings.

In addition, another of the main limitations of the study is related to the research it-self. Although representative, it is limited to immigrant students from southern Spain. Therefore, extrapolation of the data must be carried out with caution.

Despite these limitations, the study contributes to expanding the existing scientific knowledge on the social skills of immigrant students in online learning settings. Additionally, educational specialists should consider our findings in order to make prevention and intervention decisions that improve said skills and, consequently, the social wellbe-ing and academic success of these students. At present, it is undeniable that the research conducted in this study is highly relevant if one takes into account the constant migratory growth of educational centers and the increase in racist and xenophobic cyber violence.

Author Contributions: C.F.-L., M.T.-F. and J.M.O.-M. conceived the hypothesis of this study. J.M.O.M. participated in data collection. All authors analyzed the data. All authors contributed to data interpretation of the statistical analysis and wrote the paper with significant input. All authors have read and agreed to the published version of the manuscript.

Funding: This research was funded by the following I + D + I Project: "The Role of Personal Learning Environments in the Social Integration of Unaccompanied Foreign Minors (MENAS): $500 €^{\prime \prime}$.

Institutional Review Board Statement: Not applicable.

Informed Consent Statement: Not applicable.

Data Availability Statement: Not applicable.

Conflicts of Interest: The authors declare no conflict of interest.

\section{References}

1. Rodríguez-Izquierdo, R.M.; González-Faraco, J.C. Culturally relevant education: A pedagogical model for students from culturally diverse backgrounds. Concept, possibilities and limitations. Rev. Interuni. 2021, 33, 153-172.

2. Gómez-Flors, M.D.; Alguacil, M. The impact of immigrant diversity on wages. The Spanish experience. Sustainability 2018, 10, 3312. [CrossRef]

3. Tomé-Fernández, M.; Fernández-Leyva, C.; Olmedo-Moreno, E.M. Exploratory and confirmatory factor analysis of the social skills scale for young immigrants. Sustainability 2020, 12, 6897. [CrossRef] 
4. Abrougui, K.; Gabsi, K.; Mercatoris, B.; Khemis, C.; Amami, R.; Chehaibi, S. Prediction of organic potato yield using tillage systems and soil properties by artificial neural network (ANN) and multiple linear regressions (MLR). Soil Tillage Res. 2019, 190, 202-208. [CrossRef]

5. Kern, C.; Stefan, T.; Hinrichs, J. Multiple linear regression modeling: Prediction of cheese curd dry matter during curd treatment. Food Res. Int. 2019, 121, 471-478. [CrossRef]

6. Papadopoulos, A.; Stark, R.B. Does Home Health Care Increase the Probability of 30-Day Hospital Readmissions? Interpreting Coefficient Sign Reversals, or Their Absence, in Binary Logistic Regression Analysis. Am. Stat. 2020, 1-12. [CrossRef]

7. McGee, E. "Black Genius, Asian Fail": The Detriment of Stereotype Lift and Stereotype Threat in High-Achieving Asian and Black STEM Students. AERA Open 2018, 4, 1-16. [CrossRef]

8. Song, Y.; Huang, B.; He, Q.; Chen, B.; Wei, J.; Mahmood, R. Dynamic assessment of PM2.5 exposure and healthrisk using remote sensing and geo-spatial big data. Environ. Pollut. 2019, 253, 288-296. [CrossRef]

9. Alba, R.; Duyvendak, J.W. What about the mainstream? Assimilation in super-diverse times. Ethn. Racial. Stud. 2019, 42, 105-124. [CrossRef]

10. Houri, A.K.; Sullivan, A.L. Relations of social-emotional functioning and kindergarten academic achievement in children of immigrants. Psychol. Sch. 2019, 56, 1413-1433. [CrossRef]

11. Liu-Farrer, G.; Yeoh, B.S.; Baas, M. Social construction of skill: An analytical approach toward the question of skill in cross-border labour mobilities. J. Ethn. Migr. Stud. 2021, 47, 2237-2251. [CrossRef]

12. Bonal, X.; González, S. The impact of lockdown on the learning gap: Family and school divisions in times of crisis. Int. Rev. Educ. 2020, 66, 635-655. [CrossRef]

13. Hull, M.; Norris, J. The skill development of children of immigrants. Eco. Educ. Rev. 2020, 78, 1-17. [CrossRef]

14. Tsurumi, T.; Yamaguchi, R.; Kagohashi, K.; Managi, S. Are Cognitive, Affective, and Eudaimonic Dimensions of Subjective Well-Being Differently Related to Consumption? Evidence from Japan. J. Hap. Stud. 2020, 1-24. [CrossRef]

15. Kizbes, K.; Abide, F. The Effect of Social Skills Training on Social Skills in Early Childhood, the Relationship between Social Skills and Temperament. Edu. Sci. 2017, 42, 185-204. [CrossRef]

16. Gökel, Ö.; Dağlı, G. Effects of Social Skill Training Program on Social Skills of Young People. Eurasia J. Math. Sci. Technol. Educ. 2017, 13, 7365-7373. [CrossRef]

17. Choi, S.; Lee, M. Diversity as an opportunity or a challenge? A cross-national study of ethnic diversity and students' generalized trust. Int. J. Educ. Res. 2021, 80, 1-11. [CrossRef]

18. Sariyatun; Suryani, N.; Sutimin, L.A.; Abidin, N.F.; Akmal, A. The Effect of Digital Learning Material on Students' Social Skills in Social Studies Learning. Int. J. Instr. 2021, 14, 417-432. [CrossRef]

19. Tompkins, V.; Villaruel, E. Parent discipline and pre-schoolers' social skills. Early Child Dev Care. 2020, 1-15. [CrossRef]

20. Hamaidi, D.A.; Mattar, J.W.; Arouri, Y.M. Emotion Regulation and Its Relationship to Social Competence Among Kindergarten Children in Jordan. Eur. J. Contemp. Educ. 2021, 10, 66-76. [CrossRef]

21. Othman, A.; Ruslan, N. Intercultural communication experiences among students and teachers: Implication to in-service teacher professional development. J. Multicult. Educ. 2020, 14, 223-238. [CrossRef]

22. Buchanan, Z.E.; Abu-Rayya, H.M.; Kashima, E.; Paxton, S.J. The Interconnection between Acculturation and Subjective and Social Wellbeing among Refugee Youth in Australia. J. Refug. Stud. 2016, 1-19. [CrossRef]

23. Baeva, I.A.; Gayazova, L.A.; Kondakova, I.V.; Laktionova, E.B. Psychological Security and Social Intelligence in Adolescents and Young People. Psychol. Soc. Educ. 2021, 26, 5-16. [CrossRef]

24. Álvarez de Sotomayor, A.; Martínez-Cousinou, G. ¿Capital económico o cultural? El efecto del origen social sobre las desventajas académicas de los hijos de inmigrantes en España. Pap. Rev. Soc. 2016, 101, 527-554. [CrossRef]

25. Meneghel, I.; Boix, Q.; Salanova, M. Resiliencia y autoeficacia como mecanismos psicológicos que favorecen el éxito académico. Dedica. R. Edu. H. 2021, 18, 153-171. [CrossRef]

26. Goegan, L.D.; Daniels, L.M. Academic Success for Students in Postsecondary Education: The Role of Student Characteristics and Integration. J. Coll. Stud. Ret. 2019, 1-27. [CrossRef]

27. Cook, K.D.; Coley, R.L. School transition practices and children's social and academic adjustment in kindergarten. J. Educ. Psychol. 2017, 109, 166-177. [CrossRef]

28. Pareja de Vicente, D.; Alcalá del Olmo-Fernández, M.J.; Santos-Villalba, M.J.; Leiva-Olivencia, J.J. A Qualitative Study on the Intercultural Educational Sensitivity of the Professors at the University of Malaga (Spain). Educ. Sci. 2021, 11, 74. [CrossRef]

29. Göbel, K.; Preusche, Z.M. Emotional school engagement among minority youth: The relevance of cultural identity, perceived discrimination, and perceived support. Interc. Edu. 2019, 1-17. [CrossRef]

30. Medina, R. La construcción sociodiscursiva de la identidad del inmigrante latinoamericano en Barcelona. Soc. Educ. Hist. 2017, 6, 116-141. [CrossRef]

31. Tuters, S.; Portelli, J. Ontario school principals and diversity: Are they prepared to lead for equity? Int. J. Educ. Manag. 2017, 31, 598-611. [CrossRef]

32. Martín, R. Acculturation studies in spain in the last decade. Psychol. Pap. 2017, 38, 125-134.

33. Bobowik, M.; Wlodarczyk, A.; Lay-Lisboa, S. Dark and Bright Side of Claiming Discrimination: Making Attributions to Prejudice and Social Wellbeing among Immigrants in Spain. Univ. Psychol. 2018, 16, 1-15. [CrossRef] 
34. Starck, A.; Gutermann, J.; Schouler-Ocak, M.; Jesuthasan, J.; Bongard, S.; Stangier, U. The Relationship of Acculturation, Traumatic Events and Depression in Female Refugees. Front. Psychol. 2020, 11, 1-9. [CrossRef] [PubMed]

35. Birkelund, J.F. Aiming High and Missing the Mark? Educational Choice, Dropout Risk, and Achievement in Upper Secondary Education among Children of Immigrants in Denmark. Eur. Sociol. Rev. 2019, 1-18. [CrossRef]

36. Garreta-Bochaca, J.; Macia-Bordalba, M.; Llevot-Calvet, N. Intercultural Education in Catalonia (Spain): Evolution of Discourses and Practices (2000-2016). Estud. Educ. 2020, 38, 191-215.

37. Silva, C.; Bajzath, A.; Lemkow-Tovias, G.; Wastijn, B. Encouraging intercultural attitudes and practices in contemporary ECEC services. Insights from the research conducted in Italy, Spain, and Hungary. Eur. Early Child. Educ. Res. J. 2020, 28, 90-103. [CrossRef]

38. Suarez, B.F.; Varela, V.V.; De Palma, R. Intercultural priorities among immigrant organizations in Galicia (Spain): Beyond the offensive and defensive binary. Int. J. Intercult. Relat. 2020, 79, 135-144. [CrossRef]

39. Vargas, V.; Conchell, R.; Expósito-Álvarez, C.; Lila Murillo, M. Differences between Latin American and Spanish men in a batterer intervention programme: Proximal and final outcomes. An. Psicol. 2020, 36, 418-426. [CrossRef]

40. Kunesova, K. The Teaching of Interculturality through Literature: New Challenges. Rev. Electr. Interuni. Form. Prof. 2020, 23, 21-31.

41. Garrard, K.A. Finding a way in for interculturality: Analysing History teachers' conceptualisations at the secondary school level. Discourse Stud. Cult. Polit. Educ. 2020, 1-13. [CrossRef]

42. Martínez, D.; Muñoz, W.; Mondaca, C. Racism, Interculturality, and Public Policies: An Analysis of the Literature on Migration and the School System in Chile, Argentina, and Spain. SAGE Open 2020, 11, 1-12. [CrossRef]

43. Pineda, P.; Celis, J.; Rangel, L. On interculturality and Decoloniality: Sabedores and government protection of indigenous knowledge in Bacatá schools. Compare J. Comp. Intercult. Educ. 2019, 1-18. [CrossRef]

44. Sacavino, S.B. Interculturalidade e Práticas Pedagógicas: Construindo caminhos. Educação 2020, 45, 1-18. [CrossRef]

45. Chocobar, C.N. Creación surrealista de sueños colectivos en Educación Primaria. Investigación-acción intercultural. Educ. S. XXI 2020, 38, 363-382. [CrossRef]

46. Szelei, N.; Tinoca, L.; Pinho, A.S. Rethinking "cultural activities": An examination of how teachers utilised student voice as a pedagogical tool in multicultural schools. Teach. Teach. Educ. 2019, 79, 176-187. [CrossRef]

47. Brown, J.C.; Graves, E.M.; Burke, M.A. Involvement, Engagement, and Community: Dimensions and Correlates of Parental Participation in a Majority-Minority Urban School District. Urban Educ. 2020, 1-36. [CrossRef]

48. Kirmizi, F.S. The Effect of Creative Drama Activities on Immigrant Students' Life Satisfaction. Adv. Sci. Lett. 2018, 24, 3357-3361. [CrossRef]

49. Ion, G.; Sánchez, A.; Agud, I. Giving or receiving feedback: Which is more beneficial to students' learning? Assess. Eval. High. Educ. 2018, 1-15. [CrossRef]

50. Kerklaan, J.; Hannan, E.; Hanson, C.; Guha, C.; Cho, Y.; Christian, M.; Hamiwka, L.; Ryan, J.; Sinha, A.; Wong, G.; et al. Perspectives on life participation by young adults with chronic kidney disease: An interview study. BMJ Open 2020, 10, 1-12. [CrossRef]

51. Gunnthorsdottir, H.; Barille, S.; Meckl, M. Immigrant students: Parents' and teachers' experience of learning and teaching. Imarit um uppeldi og menntun-iceland. J. Educ. 2017, 26, 21-41. [CrossRef]

52. Gibson, J.L.; Newbury, D.F.; Durkin, K.; Pickles, A.; Conti-Ramsden, G.; Toseeb, U. Pathways from the early language and communication environment to literacy outcomes at the end of primary school; the roles of language development and social development. Oxf. Rev. Educ. 2020, 1-24. [CrossRef]

53. Quinones, H.T. Social Skills and Educational Strategies for Leadership Training in Primary and Secondary Education. Rev. Educ. 2020, 44, 661-665.

54. Álvarez-Hernández, L.R.; Choi, Y.J. Reconceptualizing culture in social work practice and education: A dialectic and uniqueness awareness approach. J. Soc. Work Educ. 2017, 53, 384-398. [CrossRef]

55. Arjona, M.D.S.; del Aguila, L.M.G.; Gutierrez-Perez, R. The key Competence Cultural Awareness and Creativity as a tool to vindicate the Spanish-Arabian literary heritage in an intercultural educational context. Tercio Creciente 2018, 13, 57-78.

56. Keyes, C.L.M. Social Well-Being. Am. Sociol. Assoc. 1998, 61, 121-140. [CrossRef]

57. Cutri, R.M.; Mena, J.; Whiting, E.F. Faculty readiness for online crisis teaching: Transitioning to online teaching during the COVID-19 pandemic. Eur. J. Teach. Educ. 2020, 43, 523-541. [CrossRef]

58. O'Dowd, R. A transnational model of virtual exchange for global citizenship education. Lang. Teach. 2019, 1-14. [CrossRef]

59. Esteban, I.F.; Aguilar, A.B.; Gomez, S.M.; Becerra-Brito, C.; Moreira, M.A. Perceptions on the educational impact of COVID-19: Analysis of a TECNOEDU Webinar. Int. J. Edu. Res. Inn. 2021, 15, 519-532. [CrossRef]

60. García, Á.P. La enseñanza online post pandemia: Nuevos retos. Holos 2021, 37, 1-13. [CrossRef]

61. Mielgo-Conde, I.; Seijas-Santos, S.; Grande-de-Prado, M. Review about Online Educational Guidance during the COVID-19 Pandemic. Educ. Sci. 2021, 11, 411. [CrossRef]

62. Gautam, S.; Imteyaz, S.P.; Alam, M.I. COVID-19 Pandemic: Assessment of Stress and Perception of E-Learning amongst First Year Undergraduate Medical Students. J. Clin. Diagnostic Res. 2021, 15, 1-4. [CrossRef]

63. Portillo, J.; Garay, U.; Tejada, E.; Bilbao, N. Self-Perception of the Digital Competence of Educators during the COVID-19 Pandemic: A Cross-Analysis of Different Educational Stages. Sustainability 2020, 12, 128. [CrossRef] 
64. Ley Organica 3/2020 de 29 de Diciembre, Por la que se Modifica la ley Orgánica 2/2006, de 3 de Mayo, de Educación. Boletín Oficial del Estado, 340, sec, 1, de 30 de Diciembre de 2020, 122868 a 122953 . Available online: https:/ / www.boe.es/boe/dias/20 20/12/30/pdfs/BOE-A-2020-17264.pdf (accessed on 14 September 2021).

65. Moral, A.M.; Jurado, E.B.; Ucles, D.F.; Viruel, M.J.M.; Poyatos, R.P. Second degree cooperativism and ICT adoption. CIRIEC-Esp. Rev. Eco. Públ. Soc. Coop. 2020, 100, 67-85. [CrossRef]

66. Cranfield, D.J.; Tick, A.; Venter, I.M.; Blignaut, R.J.; Renaud, K. Higher Education Students' Perceptions of Online Learning during COVID-19-A Comparative Study. Educ. Sci. 2021, 11, 403. [CrossRef]

67. Area-Moreira, M.; Bethencourt-Aguilar, A.; Martín-Gómez, S.; San Nicolás-Santos, M.B. Análisis de las políticas de enseñanza universitaria en España en tiempos de Covid-19. La presencialidad adaptada. Rev. Edc. Dis. 2021, 65, 1-19. [CrossRef]

68. Goldenthal, E.; Park, J.; Liu, S.X.; Mieczkowski, H.; Hancock, J.T. Not All AI are Equal: Exploring the Accessibility of AI-Mediated Communication Technology. Comput. Hum. Behav. 2021, 125, 1-9. [CrossRef]

69. Rodríguez-Hidalgo, A.J.; Solera, E.; Calmaestra, J. Psychological predictors of cyberbullying according to ethnic-cultural origin in adolescents: A national study in spain. J. Cross-Cult. Psychol. 2018, 49, 1506-1522. [CrossRef]

70. Tesfai, R. Does Country Context Matter? Sub-Saharan and North African Immigrants' Labour Market Outcomes in France and Spain. Int. Migr. 2018, 1-20. [CrossRef]

71. Santana, L.E.; Feliciano, L.; Jiménez, A.B. Apoyo familiar percibido y proyecto de vida del alumnado inmigrante de Educación Secundaria. Rev. Edu. 2016, 372, 35-58. [CrossRef]

72. Gil-Hernandez, C.J.; Gracia, P. Adolescents' educational aspirations and ethnic background: The case of students of African and Latin American migrant origins in Spain. Demogr. Res. 2018, 38, 577-618. [CrossRef]

73. Heaslip, V.; Hean, S.; Parker, J. Lived Experience of Vulnerability from a Gypsy Roma Traveller Perspective. J. Clin. Nurs. 2016, 25, 1987-1998. [CrossRef] [PubMed]

74. Bayraktar, F.; Machackova, H.; Dedkova, L.; Cerna, A.; Ševčíková, A. Cyberbullying: The discriminant factors among cyberbullies, cybervictims, and cyberbully-victims in a Czech adolescent sample. J. Interpers. Violence 2015, 30, 3192-3216. [CrossRef]

75. Ortiz-Marcos, J.M.; Tomé-Fernández, M.; Fernández-Leyva, C. Cyberbullying Analysis in Intercultural Educational Environments Using Binary Logistic Regressions. Future Internet 2021, 13, 15. [CrossRef]

76. Myers, M. An inheritance of exclusion: Roma education, genetics and the turn to biosocial solutions. Res. Educ. 2019, 1-17. [CrossRef]

77. Llevot, N.; Bernad, O. La mediación gitana: Herramienta performativa de las relaciones entre escuela y familia. Rev. Elect. Inter. For. Prof. 2016, 19, 99-110. [CrossRef]

78. Keung, C.P.C.; Ho, E.S.C. Estructura y agencia en las expectativas de los adolescentes de seguir la educación postsecundaria. Res. High. Educ. 2020, 61, 270-295. [CrossRef]

79. Atkin, A.L.; Yoo, H.C.; Jager, J.; Yeh, C.J. Internalization of the model minority myth, school racial composition, and psychological distress among Asian American adolescents. Asian. Am. J. Psychol. 2018, 9, 108-116. [CrossRef]

80. Cao, C.; Zhu, P.; Meng, Q. An exploratory study of inter-relationships of acculturative stressors among Chinese students from six European union (EU) countries. Int. J. Intercult. Relat. 2016, 55, 8-19. [CrossRef]

81. Yip, M.C.W. The linkage among academic performance, learning strategies and self-efficacy of Japanese university students: A mixed-method approach. Stud. High. Educ. 2019, 1-13. [CrossRef]

82. Zhang, H.; Stapleton, C.M.; Hsueh, Y.; Sun, F. “Get encouraged through failures. Failures are not fearful. We can always start over again": Chinese children's lived experiences of zi zun. Qual. Res. Psychol. 2018, 1-27. [CrossRef]

83. Jia, X.J.; Liu, X. Perceived discrimination and antisocial behaviour among Chinese rural-to-urban migrant adolescents: Mediating effects of social support. Int. J. Psychol. 2017, 52, 327-335. [CrossRef] [PubMed]

84. Trieu, M.M.; Lee, H.C. Asian americans and internalized racial oppression: Identified, reproduced, and dismantled. Soc. Race Ethn. 2017, 4, 67-82. [CrossRef]

85. Jasis, P. Latino immigrant parents and schools: Learning from their journeys of empowerment. J. Lat. Educ. 2019, 1-12. [CrossRef]

86. Volk, D. Constructing Literacy Spaces in Low-Income Homes and Communities: A Study of Two Latino First Graders and Their Families. Urban Educ. 2017, 56, 61-90. [CrossRef]

87. Simpkins, S.D.; Liu, Y.; Hsieh, T.-Y.; Estrella, G. Supporting Latino high school students' science motivational beliefs and engagement: Examining the unique and collective contributions of family, teachers, and friends. Educ. Psychol. 2019, 1-21. [CrossRef]

88. Boutakidis, I.; Rodriguez, J.L. Academic Motivation and Engagement across Three Generations of Latino/a Junior High School Students. J. Lat. Educ. 2019, 1-14. [CrossRef]

89. INE (Instituto Nacional de Estadística, Statistics National Institute). Demografía y Población. 2020. Available online: https: / / www.ine.es/dyngs/INEbase/es/categoria.htm?c=Estadistica_P\&cid=1254735572981 (accessed on 15 September 2021).

90. Giraldo-García, R.J.; Galletta, A.; Bagaka's, J.G. The intersection of culture and institutional support for Latino students' academic success: Remediation or empowerment? J. Lat. Educ. 2018, 1-13. [CrossRef]

91. Jung, Y.; Zuniga, S.; Howes, C.; Jeon, H.-J.; Parrish, D.; Quick, H.; Manship, k.; Hauser, A. Improving Latino children's early language and literacy development: Key features of early childhood education within family literacy programmes. Early Child. Dev. Care 2015, 186, 845-862. [CrossRef] 
92. Falcon, M.A.H. Student political practices in Cordoba National University. An analysis through the figure of student center. Rev. Cien. Soc. Hum. 2021, 30, 138-162. [CrossRef]

93. Montt, G.; Borgonovi, F. Combining Achievement and Well-Being in the Assessment of Education Systems. Soc. Indic. Res. 2017, 138, 271-296. [CrossRef]

94. Rodríguez-Hidalgo, A.J.; Mero, O.; Solera, E.; Herrera-López, M.; Calmaestra, J. Prevalence and psychosocial predictors of cyberaggression and cybervictimization in adolescents: A Spain-Ecuador transcultural study on cyberbullying. PLoS ONE 2020, 15, e0241288. [CrossRef]

95. Kim, S.; Faith, M.S. Cyberbullying and ICT use by immigrant youths: A serial multiple-mediator SEM analysis. Child. Youth Serv. Rev. 2020, 110, 1-11. [CrossRef]

96. Fuentes, A.; Moreno, A.J.; Pozo, J.S.; Rodríguez-García, A.M. Bullying among Teens: Are Ethnicity and Race Risk Factors for Victimization? A Bibliometric Research. Educ. Sci. 2019, 9, 220. [CrossRef]

97. Kenny, K.S.; Merry, L.; Brownbridge, D.A.; Urquia, M.L. Factors associated with cyber-victimization among immigrants and non-immigrants in Canada: A cross-sectional nationally-representative study. BMC Public. Health 2020, 20, 1-13. [CrossRef] [PubMed]

98. Fernández-Antelo, I.; Cuadrado-Gordillo, I.; Martín-Mora Parra, G. Determining Factors in the Perception of Cyberbullying in Victimized Adolescents: Psychoeducational Implications. Int. J. Emerg. Technol. Learn. 2020, 15, 38-51. [CrossRef]

99. Chwialkowska, A. Underemployment of skilled selfinitiated expatriates-A skill mismatch or categorisation? J. Educ. Work 2020, 1-18. [CrossRef]

100. Pozo, J.I.; Pérez, M.P.; Cabellos, B.; Sánchez, D.L. Teaching and Learning in Times of COVID-19: Uses of Digital Technologies During School Lockdowns. Front. Psychol. 2021, 12. [CrossRef]

101. Ahmed, V.; Opoku, A. Technology supported learning and pedagogy in times of crisis: The case of COVID-19 pandemic. Educ. Inf. Technol. 2021, 1-14. [CrossRef]

102. Matere, I.M.; Weng, C.; Astatke, M.; Hsia, C.-H.; Fan, C.-G. Effect of design-based learning on elementary students computational thinking skills in visual programming maker courseInteract. Learn. Environ. 2021, 1-14. [CrossRef]

103. Williamson, G.; Osa, M.L.; Budd, E.; Kelly, N.R. Weight-related teasing is associated with body concerns, disordered eating, and health diagnoses in racially and ethnically diverse young men. Body Image 2021, 38, 37-48. [CrossRef]

104. Maksum, A.; Widiana, I.W.; Marini, A. Path Analysis of Self-Regulation, Social Skills, Critical Thinking and Problem-Solving Ability on Social Studies Learning Outcomes. Int. J. Curric. Instr. 2021, 14, 613-628. [CrossRef]

105. Dorji, R.; Bailey, J.; Paterson, D.; Graham, L.; Miller, J. Bhutanese teachers' attitudes towards inclusive education. Int. J. Incl. Educ. 2019, 1-20. [CrossRef]

106. Sampson, M.; Parrish, D.E.; Washburn, M. Behavioral Health Training to Address the Needs of Adolescents: Outcomes of the GLOBE Youth Program. J. Soc. Work Educ. 2021, 1-18. [CrossRef]

107. Su, Y.C. Assessing Taiwanese college students' intercultural sensitivity, EFL interests, attitudes toward native English speakers, ethnocentrism, and their interrelation. Asia-Pac. Educ. Res. 2018, 27, 217-226. [CrossRef]

108. Yeh, H.C.; Tseng, S.S.; Heng, L. Enhancing EFL students' intracultural learning through virtual reality. Interact. Learn. Environ. 2020, 1-10. [CrossRef]

109. Hojnoski, R.L.; Missall, K.N.; Wood, B.K. Measuring Engagement in Early Education: Preliminary Evidence for the Behavioral Observation of Students in Schools-Early Education. Assess. Eff. Interv. 2018, 1-12. [CrossRef]

110. Lacoste, Y.; Dancause, K.N.; Gosselin-Gagne, J.; Gadais, T. Physical Activity Among Immigrant Children: A Systematic Review. J Phys. Act. Health 2020, 17, 1047-1058. [CrossRef]

111. Moise, R.K.; Meca, A.; Schwartz, S.J.; Unger, J.B.; Lorenzo-Blanco, E.I.; Ángel, M.; Szapocznik, J.; Piña-Watson, B.; Des, S.E.; Baezconde-Garbanati, L.; et al. The use of cultural identity in predicting health lifestyle behaviors in Latinx immigrant adolescents. Cult. Divers. Ethn. Minor. Psychol. 2019, 25, 371-378. [CrossRef]

112. Schmerse, D.; Zitzmann, S. Early school adjustment: Do social integration and persistence mediate the effects of school-entry skills on later achievement? Learn Instr. 2021, 71, 1-12. [CrossRef]

113. Cabrera, N.J.; Malin, J.L.; Kuhns, C.; West, J. The early home environment of latino boys and their peers: A developmental perspective. Infant Ment. Health J. 2016, 38, 97-114. [CrossRef] [PubMed]

114. Solhaug, T.; Nørgaard, N. Gender and intercultural competence: Analysis of intercultural competence among upper secondary school students in Denmark and Norway. Educ. Psychol. 2019, 1-21. [CrossRef]

115. MacCormack, J.K.; Castro, V.L.; Halberstadt, A.G.; Rogers, M.L. Mothers' interoceptive knowledge predicts children's emotion regulation and social skills in middle childhood. Soc. Dev. 2020, 29, 578-599. [CrossRef]

116. Nishimura, T.; Bradshaw, E.L.; Deci, E.L.; Ryan, R.M. Satisfaction of Basic Psychological Needs in an Interdependence Model of Fathers' Own Aspirations and Those of Their Adolescent Children. Soc. Dev. 2020, 1-18. [CrossRef]

117. Beltrán-Velasco, A.I.; Mendoza-Castejón, D.; Fuentes-García, J.P.; Clemente-Suárez, V.J. Behavioural, psychological, and physiological stress markers and academic performance in immigrant and non-immigrant preschool and school students. Physiol. Behav. 2020, 225, 1-6. [CrossRef]

118. Castaño, A.; Martínez, F.; Perianez, I. Andalusia at the crossroads of Europeanness: Immigration as a performance of coloniality. Patt. Prejud. 2017, 51, 69-88. [CrossRef] 
119. Zhang-Yu, C.; García-Díaz, S.; García-Romero, D.; Lalueza, J.L. Funds of identity and self-exploration through artistic creation: Addressing the voices of youth. Mind Cult. Act. 2020, 1-14. [CrossRef]

120. Naeyun, L.; Cheol-Sung, L. Relational skill assets and anti-immigrant sentiments. Soc. Sci. Res. 2015, 52, 270-289. [CrossRef]

121. De los Ríos, C.V. Translingual Youth Podcasts as Acoustic Allies: Writing and Negotiating Identities at the Intersection of Literacies, Language and Racialization. J. Lang. Identidad Educ. 2020, 1-15. [CrossRef]

122. Sánchez-Ojeda, M.A.; Navarro-Prado, S.; Martín-Salvador, A.; Luque-Vara, T.; Fernández-Gómez, E.; Del Pino, F.J.P. Nursing students' attitudes towards immigrants' social rights. Int. J. Environ. Res. Public Health 2020, 17, 8875. [CrossRef]

123. Park, I.J.K.; Wang, L.; Williams, D.R.; Alegría, M. Coping With Racism: Moderators of the Discrimination-Adjustment Link Among Mexican-Origin Adolescents. Child Dev 2018, 89, 293-310. [CrossRef]

124. Atani, L. Psychiatry and intrafamily violence. When to say alienates. Annal. Med.-Psychol. 2020, 178, 525-529. [CrossRef]

125. Assari, S.; Cobb, S.; Cuevas, A.G.; Bazargan, M. Diminished Health Returns of Educational Attainment Among Immigrant Adults in the United States. Front. Psychiatry 2020, 11, 1-13. [CrossRef]

126. Franco, D. Trauma without borders: The necessity for school-based interventions in treating unaccompanied refugee minors. Child Adolesc. Soc. Work J. 2018, 35, 551-565. [CrossRef] [PubMed]

127. Kettrey, H.H. "Bad girls" say no and "good girls" say yes: Sexual subjectivity and participation in undesired sex during heterosexual college hookups. Sex. Cult. 2018, 22, 685-705. [CrossRef]

128. Ciftci, S. Self-expression values, loyalty generation, and support for authoritarianism: Evidence from the Arab world. Democratization 2018, 25, 1132-1152. [CrossRef]

129. Alivernini, F.; Cavicchiolo, E.; Manganelli, S.; Chirico, A.; Lucidi, F. Students' psychological well-being and its multilevel relationship with immigrant background, gender, socioeconomic status, achievement, and class size. Sch. Eff. Sch. Improv. 2020, 31, 172-191. [CrossRef]

130. Klimeckil, O.M.; Sander, D.; Vuilleumier, P. Distinct brain areas involved in anger versus punishment during social interactions. Sci. Rep. UK 2018, 8, 1-12.

131. Giugni, M.; Grasso, M. Trust, identity, skills, ¿or recruitment? Assessing four explanations of the relationship between associational involvement and the political participation of migrants. Int. Migr. Rev. 2020, 54, 585-610. [CrossRef]

132. Hensel, D.J.; Tanner, A.E. Daily emotional and behavioral interactions in young men's and young women's single and multiple partner relationships. J. Adolesc. Health 2015, 56, 5-6. [CrossRef]

133. Pérez, C. Técnicas Estadísticas Predictivas con IBM SPSS Modelos; Garceta: Madrid, Spain, 2014; pp. 1-474.

134. Campbell, H.; Lakens, D. Can we disregard the whole model? Omnibus non-inferiority testing for R-2 in multi-variable linear regression and eta boolean AND 2 in ANOVA. Br. J. Math. Stat. Psychol. 2020, 1-26. [CrossRef]

135. Bayrakdar, S.; Guveli, A. Understanding the benefits of migration: Multigenerational transmission, gender and educational outcomes of Turks in Europe. J. Ethn. Migr. Stud. 2020, 1-22. [CrossRef]

136. Pallmann, P.; Jaki, T. Simultaneous confidence regions for multivariate bioequivalence. Stat. Med. 2017, 36, 4585-4603. [CrossRef]

137. Gbadamosi, G.; Evans, C.; Richardson, M.; Chanthana, Y. Understanding self-efficacy and the dynamics of part-time work and career aspiration. High. Educ. Skills Work-Based Learn. 2019, 9, 468-484. [CrossRef]

138. Bijsterbosch, J.; Harrison, S.; Duff, E.; Alfaro-Almagro, F.; Woolrich, M.; Smith, S. Investigations into within- and between-subject resting-state amplitude variations. Neuroimage 2017, 159, 57-69. [CrossRef] [PubMed]

139. Kim, Y.K.; Park, E.; Lee, A.; Im, C.H.; Kim, Y.-H. Changes in network connectivity during motor imagery and execution. PLoS ONE 2018, 13, e0190715.

140. Linke, A.C.; Mash, L.E.; Fong, C.H.; Kinnear, M.K.; Kohli, J.S.; Wilkinson, M.; Tung, R.; Jao Keehn, R.J.; Carper, R.A.; Fishman, I.; et al. Dynamic time warping outperforms Pearson correlation in detecting atypical functional connectivity in autism spectrum disorders. Neuroimage 2020, 223, 1-15. [CrossRef]

141. Ordones, S.; Servin, M.; Padilla, M.; Choque, I.; Muñoz, A.; Flores, J.L. Tukey's robust M-estimator for phase demodulation of interferograms with nonuniform shifts. Appl. Opt. 2020, 59, 6224-6230. [CrossRef]

142. Machado-Casas, M.; Andrés, S.; Talati-Espinza, K.; Abdul-Razaq, H. Working with immigrant and refugee families: Broadening cross-cultural understanding with immigrant/refugee families. Foro Educ. 2018, 16, 193-205. [CrossRef]

143. Chen, Y.; Mayall, H.J.; York, C.S.; Smith, T.J. Parental perception and English Learners' mobile-assisted language learning: An ethnographic case study from a technology-based Funds of Knowledge approach. Learn. Cult. Soc. Interact. 2019, 22, 1-9. [CrossRef]

144. Halimi, F.; AlShammari, I.; Navarro, C. Emotional intelligence and academic achievement in higher education. J. Appl. Res. High. Educ. 2020, 1-19. [CrossRef]

145. Williams-Washington, K.N.; Mills, C.P. African American Historical Trauma: Creating an Inclusive Measure. J. Multicult. Couns. Dev. 2018, 46, 246-263. [CrossRef] 